\title{
Severe Insulin-Resistant Diabetes Mellitus in Patients with Congenital Muscle Fiber Type Disproportion Myopathy
}

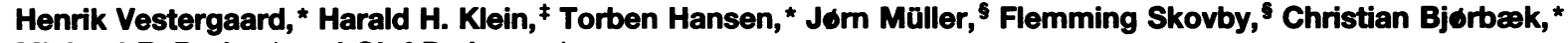 \\ Michael E. Røder, * and Oluf Pedersen* \\ * Steno Diabetes Center and Hagedorn Research Laboratory, Copenhagen, Denmark; ${ }^{\ddagger}$ Department of Internal Medicine, \\ Medical University of Lübeck, Lübeck, Germany; and ${ }^{\S}$ Department of Growth and Reproduction, National University Hospital, \\ Copenhagen, Denmark
}

\begin{abstract}
Congenital muscle fiber type disproportion myopathy (CFTDM) is a chronic, nonprogressive muscle disorder characterized by universal muscle hypotrophy and growth retardation. Histomorphometric examination of muscle shows a preponderance of smaller than normal type 1 fibers and overall fiber size heterogeneity. Concomitant endocrine dysfunctions have not been described. We report the findings of altered insulin secretion and insulin action in two brothers affected with CFTDM and glucose intolerance as well as in their nonconsanguineous glucose-tolerant parents. Results are compared with those of six normoglycemic control subjects. All study participants underwent an oral glucose tolerance test to estimate insulin secretion. The oldest boy and his parents volunteered for studies of whole-body insulin sensitivity consisting of a 4-h euglycemic hyperinsulinemic clamp in combination with indirect calorimetry. Insulin receptor function and glycogen synthase (GS) activity and expression were examined in biopsies of vastus lateralis muscle. Despite a 45-90-fold increase in both fasting and postprandial serum insulin levels, both CFTDM patients had diabetes mellitus. Clamp studies revealed that the oldest boy had severe insulin resistance of both liver and peripheral tissues. The impaired insulin-stimulated glucose disposal to peripheral tissues was primarily due to reduced nonoxidative glucose metabolism. These changes were paralleled by reduced basal values of muscle GS total activity, allosterical activation of GS by glucose-6-phosphate, GS protein, and GS mRNA. The father expressed a lesser degree of insulin resistance, and studies of muscle insulin receptor function showed a severe impairment of receptor kinase activity. In conclusion, CFTDM is a novel form of severe hyperinsulinemia and insulin resistance. Whether insulin resistance is causally related to the muscle disorder awaits to be clarified. (J. Clin. Invest. 1995. 95:1925-1932.) Key words: clamp - muscle glycogen synthase gene expression • insulin receptor kinase activity • insulin resistance • hyperinsulinemia
\end{abstract}

Address correspondence to Henrik Vestergaard, M.D., Steno Diabetes Center, Niels Steensen vej 2, DK-2820 Gentofte, Denmark. Phone: 31680800x9966; FAX: 44-438232.

Received for publication 16 August 1994.

J. Clin. Invest.

(c) The American Society for Clinical Investigation, Inc.

0021-9738/95/04/1925/08 \$2.00

Volume 95, April 1995, 1925-1932

\section{Introduction}

The association in children of congenital myopathy with nonprogressive weakness was first described by Brooke in 1973 (1) and termed congenital fiber type disproportion myopathy (CFTDM).' Since then additional case stories of children with CFTDM have been reported by several authors $(2,3)$. The clinical picture is characterized by weakness and hypotonia beginning at or shortly after birth, delayed milestones, and in some cases skeletal deformities similar to those seen in other congenital myopathies (2). Some patients may have delayed onset with mild symptoms, mainly muscle pain (3). In some families, studies of affected siblings suggest an autosomal recessive pattern of inheritance (4). Other studies have shown parental involvement pointing to an autosomal dominant mode of inheritance $(5,6)$. The diagnosis is established by morphological examination of skeletal muscle, which shows a predominance $(>55 \%)$ of small type 1 (slow-twitch oxidative) muscle fibers, at least $12 \%$ smaller than type 2 fibers, and normal or hypertrophied type 2 (fast-twitch glycolytic) fibers in the absence of other obvious histologic abnormalities (1). An excess of type 2A (fast-twitch oxidative and glycolytic) hypertrophied fibers $(1,7)$ or type $2 B$ (fast-twitch glycolytic) hypertrophied fibers $(1,2)$ has been noticed in some but not all cases $(8,9)$. The pathogenesis of the muscle disorder is unknown. Generally, the prognosis is good, with most patients showing improvement with age, although some residual motor impairment often persists. In rare cases, however, there is a progressive muscle weakness, recurrent respiratory tract infections, and respiratory failure necessitating continuous assisted ventilation (7). Morphologic studies of biopsied muscles are necessary to obtain a final diagnosis (10).

In this study we describe a family of five members, parents and three sons, of whom both the oldest and the youngest sons have CFTDM and insulin-resistant diabetes mellitus. To characterize the whole-body insulin sensitivity of the parents and of the oldest son affected with CFTDM, we have applied the euglycemic hyperinsulinemic clamp technique in combination with indirect calorimetry. Moreover, we have studied several aspects of insulin-stimulated glucose metabolism in muscle biopsies from the same individuals.

1. Abbreviations used in this paper: $\mathrm{A}_{0.5}$, concentration giving halfmaximal stimulation of an enzyme; CFTDM, congenital muscle fiber type disproportion myopathy; FFA, free fatty acid; G6P, glucose-6phosphate; GS, glycogen synthase; $\mathrm{HbA}_{\mathrm{lc}}$, glycosylated hemoglobin; HGO, hepatic glucose output; IRK, insulin receptor kinase; MD, myotonic dystrophy; NIDDM, non-insulin-dependent diabetes mellitus; OGTT, oral glucose tolerance test. 
Table I. Characteristics of the Family Members and Control Group

\begin{tabular}{lrrrrc}
\hline & Age & Height & Weight & BMI $^{*}$ & HbA $_{1 \mathrm{C}}{ }^{\ddagger}$ \\
\hline & $y r$ & $c m$ & $k g$ & $\mathrm{~kg} / \mathrm{m}^{2}$ & $\%$ \\
Proband 1 & 15 & 135 & 27 & 14.6 & 8.2 \\
Proband 2 & 8 & 117 & 17 & 12.4 & 7.1 \\
Unaffected brother & 13 & 145 & 34 & 16.2 & - \\
Mother & 37 & 160 & 56 & 21.9 & 5.5 \\
Father & 41 & 158 & 58 & 23.2 & 5.9 \\
Control group & & & & & \\
$\quad$ (mean) & 52 & 174 & 78 & 25.8 & 5.3 \\
$\quad$ (SEM) & 3 & 4 & 5 & 1.2 & 0.2 \\
\hline
\end{tabular}

* Body mass index. ${ }^{\ddagger}$ Normal range $4.1-6.1 \%$.

\section{Methods}

Subjects and study design. The probands were referred to the University Hospital in Copenhagen for evaluation of muscle disease and short stature. Clinical data of the probands and their family are presented in Table I. The two probands, brothers at 15 and $8 \mathrm{yr}$ of age, were born of nonconsanguineous healthy parents at term following uncomplicated pregnancies and deliveries. Birth weights/lengths were $2,140 \mathrm{~g} / 48 \mathrm{~cm}$ and $1,850 \mathrm{~g} / 48 \mathrm{~cm}$ in the oldest and youngest probands, respectively. Both siblings had delayed milestones and muscle weakness. At the age of $\sim 18 \mathrm{mo}$, they were both able to walk alone; however, they were not able to crawl or rise before the age of $\sim 3 \mathrm{yr}$. At the age of $6 \mathrm{yr}$, both probands were diagnosed as having CFTDM. Muscle biopsies from the children showed $74 \%$ small type 1 fibers with a diameter of $16 \mu \mathrm{m}$ (SD $3 \mu \mathrm{m}$ ) and $26 \%$ type 2 fibers with a diameter of $22 \mu \mathrm{m}$ (SD 2 $\mu \mathrm{m})$. No nemaline bodies were seen. Electromyelograms were normal in both boys, and both have a normal karyotype. Physical examination revealed universal muscle hypotrophy, and both probands were very hairy. No skin pigmentations or acanthosis nigricans was seen. The probands had normal fasting levels of serum thyroid-stimulating hormone, thyroxine, glucagon, and insulin-like growth factor-1, and 24-h urinary excretion of cortisol and growth hormones was likewise normal.

Glucosuria and postprandial hyperglycemia were discovered by chance at the age of $13 \mathrm{yr}$ in proband 1 and at $6 \mathrm{yr}$ in proband 2. None of the boys had at that time any symptoms of hyperglycemia. They had normal fasting plasma glucose levels of 5.1 and $4.2 \mathrm{mmol} / \mathrm{liter}$, respectively, but the 2 -h plasma glucose concentrations during a 1.75 $\mathrm{g} / \mathrm{kg}$ body weight oral glucose tolerance test (OGTT) showed diabetes mellitus in the oldest proband, with a plasma glucose of $15.2 \mathrm{mmol} /$ liter and glucose intolerance in the youngest proband, with a plasma glucose of $8.8 \mathrm{mmol} /$ liter. Both had pronounced hyperinsulinemia at the time of the first OGTT, with fasting serum insulin levels of $\sim 1,400$ pmol/liter. The patients were prescribed a diabetes diet and followed regularly in the outpatient clinic; after $1 \mathrm{yr}$, the OGTT was repeated with similar results. The probands were now referred to Steno Diabetes Center for further evaluation and treatment. Late onset, non-insulindependent diabetes mellitus (NIDDM) was known on the maternal site of the family (the probands' great-grandmother and a sister to the grandmother had NIDDM)

Both parents (mother, $37 \mathrm{yr}$; father, $41 \mathrm{yr}$ ) and proband 1 volunteered for studies of whole-body glucose and lipid metabolism (clamp) as well as studies of in vitro muscle metabolism. The results of the clamp study, including muscle biopsies, were compared with those of six healthy control subjects (Table I) with normal fasting plasma glucose $(5.3 \pm 0.2 \mathrm{mmol} /$ liter $)$, normal blood pressure, and no family history of diabetes. None of the participants in the study suffered from liver or kidney diseases, as evaluated by clinical and standard laboratory exami- nations, and none of them were taking any medication during the investigation. The participants refrained from physical exercise and any major physical activity for $72 \mathrm{~h}$ before the examination. Before entry into the study, the purpose and risks of the experimental protocol were carefully explained to all of the volunteers, and their informed consent was obtained. The protocol was approved by the local Ethical Committee and was in accordance with the Helsinki II Declaration.

OGTT. All five family members had a standard $(1.75 \mathrm{~g} / \mathrm{kg}$ body weight in the children and $75 \mathrm{~g}$ in adults) OGTT after a 10-h overnight fast. Venous blood samples were drawn at $0,15,30,45,60,90,120$, 150 , and $180 \mathrm{~min}$ for analysis of serum insulin, serum C-peptide, and plasma glucose. Moreover, serum proinsulin levels were measured at 0,60 , and $120 \mathrm{~min}$.

Euglycemic hyperinsulinemic clamp. Each clamp lasted for $6 \mathrm{~h}$ : a 2-h basal period followed by a 4-h hyperinsulinemic glucose clamp ( 2 $\mathrm{mU}$ insulin $/ \mathrm{kg} / \mathrm{min}$ ) in combination with indirect calorimetry, infusion of tritiated glucose, and a muscle biopsy at the end of each study period. Details of the clamp technique have been described previously $(11,12)$.

Glucose disposal. Total glucose disposal rate was calculated from the concentrations of plasma tritiated glucose and plasma glucose using Steele's non-steady-state equations (13). In these calculations, the distribution volume of glucose was taken as $200 \mathrm{ml} / \mathrm{kg}$ body weight and the pool fraction as $\mathbf{0 . 6 5}$. Total peripheral glucose uptake was corrected for urinary glucose loss.

Glucose and lipid oxidation. Indirect calorimetry was performed using the flow-through canopy gas analyzer system (Deltatrac Metabolic Monitor; Datex, Helsinki, Finland). Rates of oxidation were calculated from Frayn's equation (14). The nonoxidative glucose metabolism was calculated as the difference between total glucose disposal rate and glucose oxidation, as determined by indirect calorimetry.

Muscle biopsies. Percutaneous muscle biopsies $(\sim 400 \mathrm{mg})$ were obtained under local anesthesia (1\% lidocaine without epinephrine) from the vastus lateralis muscle $\sim 20 \mathrm{~cm}$ above the knee, using a modified Bergström needle (Stille-Werner, Copenhagen, Denmark). Muscle samples were blotted to remove blood, connective tissue, and adipose tissue, frozen within $30 \mathrm{~s}$ in liquid nitrogen, and stored at $-80^{\circ} \mathrm{C}$ until assayed.

Insulin receptor binding and receptor kinase activity. Approximately $30 \mathrm{mg}$ of muscle tissue taken at basal and clamp insulin levels was minced in the frozen state and subsequently solubilized under conditions designed to preserve the phosphorylation state of the receptors as it existed in the intact tissue (15). This was achieved by immediate homogenization in an ice-cold solubilization buffer ( final concentrations: $1 \%$ Triton X-100, $2.5 \mathrm{mM}$ PMSF, 800 trypsin inhibitor, U/ml aprotinin, $8 \mathrm{mM}$ EDTA, $2.5 \mathrm{mg} / \mathrm{ml}$ benzamidine, $2.5 \mu \mathrm{g} / \mathrm{ml}$ pepstatin, $2.5 \mu \mathrm{g} / \mathrm{ml}$ leupeptin, $160 \mathrm{mM} \mathrm{NaF}, 10 \mathrm{mM}$ sodium pyrophosphate, 0.2 $\mathrm{mM}$ sodium vanadate, $2 \mathrm{mM}$ dichloracetic acid, and $20 \mathrm{mM}$ Hepes, $\mathrm{pH}$ 7.4) using a tissue grind tube (Kontes, Vineland, $\mathrm{NJ}$ ). After $20 \mathrm{~min}$ at $4^{\circ} \mathrm{C}$, the samples were centrifuged at $10^{5} \mathrm{~g}$ to remove insoluble material. The measurement of kinase activity resulting from "in vivo" stimulation was performed essentially as previously described (15) with minor modifications. Briefly, 30- $\mu \mathrm{l}$ aliquots of the solubilized muscle samples were pipetted into microwells to which anti-insulin receptor antibody had been attached. After $16 \mathrm{~h}$ at $4^{\circ} \mathrm{C}$, the wells were washed, and phosphorylation reactions were initiated in the wells by adding a mixture containing $0.05 \%$ Triton X-100, $60 \mathrm{mM} \mathrm{NaCl}, 1.5 \mathrm{mM} \mathrm{KCl}, 0.6 \mathrm{mM}$ $\mathrm{CaCl}_{2}, 0.06 \mathrm{mM}$, sodium vanadate, $12 \mathrm{mM}$ Hepes, $5 \mathrm{mM} \mathrm{MnCl}_{2}, 12$ $\mathrm{mM} \mathrm{MgCl} 2,500 \mu \mathrm{l}$ of CTP, $0.5 \mu \mathrm{M}$ ATP $(100-200 \mathrm{Ci} / \mathrm{mmol})$, and 2 $\mathrm{mg} / \mathrm{ml}$ Glu4:Tyrl (15). After $20 \mathrm{~min}$, the radioactivity incorporated into Glu4:Tyrl was determined as previously described (15). Subsequently the insulin-binding activity in the wells was determined with ${ }^{125}$ I-insulin as previously described (15).

RNA isolation. Muscle biopsies were homogenized in a $4 \mathrm{M}$ guanidinium thiocyanate solution, and subsequently, total RNA was isolated on a 341 Nucleic Acid Purification System (Applied Biosystems Inc., Foster City, CA). Quantity and purity of total RNA were determined by absorbance at 260 and $280 \mathrm{~nm}$. 
Oligonucleotides used for PCR amplification. Oligonucleotides were synthesized on an 394 DNA/RNA Synthesizer (Applied Biosystems Inc.) Fluorescein labeling of primers was done during synthesis, using the Fluor Prime Amidite (Pharmacia, P-L Biochemicals Inc., Milwaukee, WI). The human muscle glycogen synthase (GS) primers were 5'-ACCTGGCTTATTCCCAACTGCTC-3' and 5'-FAGTGACCTCAGTTCTGGATCATG- $3^{\prime}$. The rabbit $\beta$-globin primers were $5^{\prime}$-TTTGGCAAAGAATTCACTCCTCAG-3' and 5'-FGATGCTCAAGGGGCTTCATGATG-3' ( $\mathrm{F}$ = fluorescein labeling).

cDNA synthesis and PCR amplification. cDNA was synthesized from $1.0 \mu \mathrm{g}$ of total RNA in $25-\mu 1$ reactions containing $50 \mathrm{mM}$ Tris$\mathrm{HCl}$ ( $\mathrm{pH} \mathrm{8.3),} 75 \mathrm{mM} \mathrm{KCl}, 3 \mathrm{mM} \mathrm{MgCl} 2,10 \mathrm{mM}$ DTT, $0.2 \mathrm{mM}$ dNTPs, $40 \mathrm{U}$ of RNasin (Promega, Madison, WI), $0.625 \mu \mathrm{g}$ of oligo(dT) $)_{18}, 400$ U Moloney murine leukemia virus reverse transcriptase (Life Technologies, Grand Island, NY), and $2.5 \mathrm{pg}$ of rabbit globin mRNA (Clontech Laboratories Inc., Palo Alto, CA). The reactions were performed at $37^{\circ} \mathrm{C}$ for $1 \mathrm{~h}$, followed by an enzyme inactivation during incubation at $95^{\circ} \mathrm{C}$ for $10 \mathrm{~min}$. Each $50-\mu \mathrm{l}$ PCR was performed with $5 \mu \mathrm{l}$ of cDNA reaction mixture as template at standard conditions including the four oligonucleotide primers. The mixture was sealed with $25 \mu \mathrm{l}$ of mineral oil, and after initial denaturation at $95^{\circ} \mathrm{C}$ for $3 \mathrm{~min}$, the samples were subjected to PCR amplification: annealing at $55^{\circ} \mathrm{C}$ for $30 \mathrm{~s}$, extension at $72^{\circ} \mathrm{C}$ for $30 \mathrm{~s}$, and denaturation at $94^{\circ} \mathrm{C}$ for $30 \mathrm{~s}$, followed by a final extension at $72^{\circ}$ for $5 \mathrm{~min}$. The reactions were run for 17 cycles, which was within the exponential phase of the amplification for the range of GS mRNA levels found in the patients (data not shown).

Analysis of human skeletal muscle GS mRNA. $5 \mu$ l of each PCR was mixed with $5 \mu \mathrm{l}$ of stop buffer (formamide with $5 \mathrm{mg} / \mathrm{ml}$ dextran blue), denaturated at $90^{\circ} \mathrm{C}$ for $3 \mathrm{~min}$, and loaded onto a $6 \%$ denaturating premixed polyacrylamide gel (Life Technologies) on an Automated Laser Fluorescence DNA sequencer (Pharmacia). The ratio of the GS (129 bp) to rabbit globin (145 bp) fluorescein-labeled PCR products was determined by calculating the area under the curves using the Fragment Manager software (Pharmacia).

The coefficient of variation of the method is $0.10(n=10$ separate determinations in triplet).

Preparation of anti-GS antibody and GS immunoblotting. Antibody preparation and immunoblotting were performed as described in detail earlier (12). Anti-GS antibody was produced against 9 amino acids $\left(\mathrm{NH}_{2}\right.$-TSSLGEERN) in the carboxyl terminus of GS. Approximately $20 \mathrm{mg}$ of frozen muscle was homogenized, and connective tissue and insoluble cell constituents without measurable GS immunoreactivity were removed from homogenate by centrifugation. Samples, $100 \mu \mathrm{g}$ of total protein per lane, were separated in triplicate on a 10\% SDS-PAGE gel with a $4 \%$ stacking gel. A human muscle protein standard preparation was run on each gel in triplicate and used to correct for intra-gel variations in the immunoblots. Prestained molecular weight markers were purchased from Bio-Rad (Hercules, CA). The proteins were electrophoretically transferred to a $0.45-\mu \mathrm{m}$ nitrocellulose membrane. After blocking for 12-24 h, the membranes were incubated with anti-GS antiserum $(1: 50,000)$ for $12-24 \mathrm{~h}$ at $4^{\circ} \mathrm{C}$. After washing, blots were incubated with $\left[{ }^{35} \mathrm{~S}\right]$ protein A (Amersham Corp., Arlington Heights, IL). at an activity of $0.2 \mu \mathrm{Ci}$ per ml of buffer for $1 \mathrm{~h}$ at $20^{\circ} \mathrm{C}$. Quantitative scanning of autoradiograms was performed within the linear response range, as determined by the standard curve of total GS protein using a Shimadzu CS 9000 (Shimadzu Corp., Tokyo, Japan) flying spot densitometer. Studies of the immunoreactivity of GS in muscle specimens from the participants were run at the same time. When six different samples from the same muscle biopsy were analyzed, the coefficient of variation was 0.11 for GS protein

Determination of GS activity in muscle. Extraction from muscle samples, assays for GS activity, and analysis of protein content in muscle preparations were performed as described previously (16). GS activity was assayed in duplicate in the absence or presence of seven concentrations (0-6.7 mmol/liter) of glucose-6-phosphate (G6P). Total activity refers to the GS activity in the presence of a saturating concentration of G6P ( $6.7 \mathrm{mmol} /$ liter). The final concentration of UDP-glucose (un- labeled UDP-glucose + UDP- $\left[\mathrm{U}-{ }^{14} \mathrm{C}\right]$ glucose [New England Nuclear, Boston, MA]) in the reaction mixture was $0.13 \mathrm{mmol} /$ liter. GS activity was expressed as nanomoles of UDP-glucose incorporated into glycogen per minute per milligram of soluble protein in the homogenate. Fractional velocities (FV) were calculated as GS activity in the presence of subsaturating levels of G6P divided by GS activity in the presence of $6.7 \mathrm{mmol} /$ liter G6P. The concentration of G6P giving half-maximal stimulation of the GS ( $A_{0.5}$ for $G S$ ) was calculated using a Hill plot. The inter-assay coefficients of variation were 0.12 for $A_{0.5}$ and 0.13 for total GS, ( $n=10$ separate experiments $)$.

To exclude any influence of day-to-day variation, muscle samples from the participants were prepared and analyzed for GS mRNA and protein levels as well as for GS enzyme activity at the same time.

Other analytical procedures. Glucose in plasma and in urine was measured by a hexokinase method (17). Intact insulin in serum was measured applying an ELISA (18). The method uses two murine mAbs that bind to two different epitopes on the insulin molecule. The immunoassay is specific, and no proinsulin is detected by the assay. Serum Cpeptide and serum proinsulin were analyzed by RIA and ELISA techniques, respectively (19-21). For measurement of serum values of insulin, proinsulin, and C-peptide, the detection limit and coefficient of variations were $5 \mathrm{pmol} / \mathrm{liter}$ and $0.09,1.2 \mathrm{pmol} / \mathrm{liter}$ and 0.09 , and 60 $\mathrm{pmol} /$ liter and 0.08 , respectively. $\mathrm{HbA}_{1 \mathrm{C}}$ (glycosylated hemoglobin) was measured by an HPLC method (normal range 4.1-6.1\%). Tritiated glucose in plasma was analyzed as described previously (22). Free fatty acids (FFAs) in plasma were determined by the method of Itaya and Michio (23)

\section{Results}

Characterization of subjects. As seen in Table II, fasting serum insulin levels were severely increased in the CFTDM patients when compared with the parents, the healthy brother, and the control subjects (control subjects, $67 \pm 7 \mathrm{pmol} / \mathrm{liter}$ ). It also appears from the table that the glucose-tolerant father was relatively insulin resistant, as reflected by his fasting hyperinsulinemia. The ratio of fasting serum insulin/C-peptide levels was severely increased in both probands (proband 1, 131\%; proband $2,174 \%)$ and to a lesser extent in the father $(57 \%)$ when compared with the other family members (unaffected brother, $21 \%$; mother, $23 \%)$ and the control subjects $(10 \pm 1 \%)$. Thus, it seems likely that the increase in serum insulin in the probands and the father was in part associated with a substantial decrease in insulin clearance.

The increased serum insulin levels were not explained by inappropriately high levels of proinsulin, since the two-site immunoassay used does not measure human proinsulin. This was further confirmed by measuring serum proinsulin levels during the OGTT at time $0,60 \mathrm{~min}$, and $120 \mathrm{~min}$. It appears, however, that the absolute levels of serum proinsulin were increased in the two boys with CFTDM when compared with both parents and their unaffected brother (Table II). However, calculating the fasting proinsulin/insulin ratios, no increase was found in the probands compared with the other family members (proband $1,4.5 \%$; proband $2,3.7 \%$; unaffected brother, $6.9 \%$; mother, 8.9\%; father, $2.7 \%$ ). Thus, the insulin resistance in the probands does not seem to cause an increased proportion of proinsulin to be secreted.

It is also seen from Table II that both probands were diabetic in accordance to World Health Organization criteria.

Glucose and lipid metabolism in vivo. During the basal period of the clamp study, the glucose disposal rate in proband 1 was increased when compared with that of the control group 
Table II. Plasma Glucose, Serum Insulin, Serum C-peptide, and Serum Proinsulin Levels during a Standard OGTT of the Family Members

\begin{tabular}{|c|c|c|c|c|c|c|c|c|c|c|c|c|c|c|c|}
\hline & \multicolumn{4}{|c|}{ Glucose } & \multicolumn{4}{|c|}{ Insulin } & \multicolumn{4}{|c|}{ C-peptide } & \multicolumn{3}{|c|}{ Proinsulin } \\
\hline & Fasting & $2 \mathrm{~h}$ & Max. & Auc* & Fasting & $2 \mathrm{~h}$ & $\operatorname{Max}$ & $\mathrm{AUC}^{\ddagger}$ & Fasting & $2 \mathrm{~h}$ & Max. & $\mathrm{AUC}^{\ddagger}$ & Fasting & $1 \mathrm{~h}$ & $2 \mathrm{~h}$ \\
\hline & \multicolumn{4}{|c|}{$m M$} & \multicolumn{4}{|c|}{$p M$} & \multicolumn{4}{|c|}{$p M$} & \multicolumn{3}{|c|}{$p M$} \\
\hline Proband 1 & 7.9 & 21.7 & 21.7 & 1,935 & 3,031 & 7,985 & 8,756 & 690,345 & 2,320 & 6,360 & 6,640 & 536,850 & 137 & 195 & 189 \\
\hline Proband 2 & 5.5 & 12.6 & 17.1 & 1,293 & 6,000 & 9,561 & 12,942 & 389,625 & 3,440 & 5,120 & 10,720 & 597,600 & 220 & 241 & 298 \\
\hline Unaffected brother & 4.7 & 5.6 & 8.7 & 371 & 58 & 147 & 436 & 42,849 & 280 & 730 & 1,180 & 97,650 & 4 & 28 & 20 \\
\hline Mother & 5.2 & 4.8 & 8.5 & 29 & 67 & 204 & 786 & 41,018 & 290 & 620 & 2,050 & 119,025 & 6 & 17 & 10 \\
\hline Father & 5.8 & 5.7 & 12.7 & 288 & 261 & 1,752 & 3,000 & 244,598 & 460 & 1,230 & 2,420 & 136,650 & 7 & 61 & 58 \\
\hline
\end{tabular}

AUC, incremental area under the curve for $3 \mathrm{~h}$ OGTT. * (millimoles per liter) minutes. ${ }^{\ddagger}$ (picomoles per liter) minutes.

(104 and $74 \pm 3 \mathrm{mg} / \mathrm{m}^{2} / \mathrm{min}$, respectively) (Fig. 1). The increased glucose disposal rate was due to both an increased glucose oxidation rate ( 67 and $56 \pm 4 \mathrm{mg} / \mathrm{m}^{2} / \mathrm{min}$, respectively) and an increased nonoxidative glucose metabolism ( 37 versus $18 \pm 5 \mathrm{mg} / \mathrm{m}^{2} / \mathrm{min}$, respectively). Basal glucose disposal rate in the parents was comparable to that of the control group (mother, $74 \mathrm{mg} / \mathrm{m}^{2} / \mathrm{min}$; father, $69 \mathrm{mg} / \mathrm{m}^{2} / \mathrm{min}$ ). However, basal nonoxidative glucose metabolism was severely decreased in the father $\left(3 \mathrm{mg} / \mathrm{m}^{2} / \mathrm{min}\right)$, whereas the glucose oxidation rate was increased $\left(66 \mathrm{mg} / \mathrm{m}^{2} / \mathrm{min}\right)$. In the mother, both basal glucose oxidation rate $\left(56 \mathrm{mg} / \mathrm{m}^{2} / \mathrm{min}\right)$ and nonoxidative glucose metabolism $\left(18 \mathrm{mg} / \mathrm{m}^{2} / \mathrm{min}\right)$ were comparable to those in the control group (Fig. 1).

The insulin-stimulated glucose disposal rate was severely decreased in proband 1 and to a lesser degree in both parents (proband $1,146 \mathrm{mg} / \mathrm{m}^{2} / \mathrm{min}$; mother, $308 \mathrm{mg} / \mathrm{m}^{2} / \mathrm{min}$; father, $247 \mathrm{mg} / \mathrm{m}^{2} / \mathrm{min}$; control group, $381 \pm 32 \mathrm{mg} / \mathrm{m}^{2} / \mathrm{min}$ ) primarily owing to a decrease in nonoxidative glucose metabolism (proband $1,42 \mathrm{mg} / \mathrm{m}^{2} / \mathrm{min}$; mother, $183 \mathrm{mg} / \mathrm{m}^{2} / \mathrm{min}$; father, 91 $\mathrm{mg} / \mathrm{m}^{2} / \mathrm{min}$; control group, $227 \pm 24 \mathrm{mg} / \mathrm{m}^{2} / \mathrm{min}$ ) (Fig. 1).

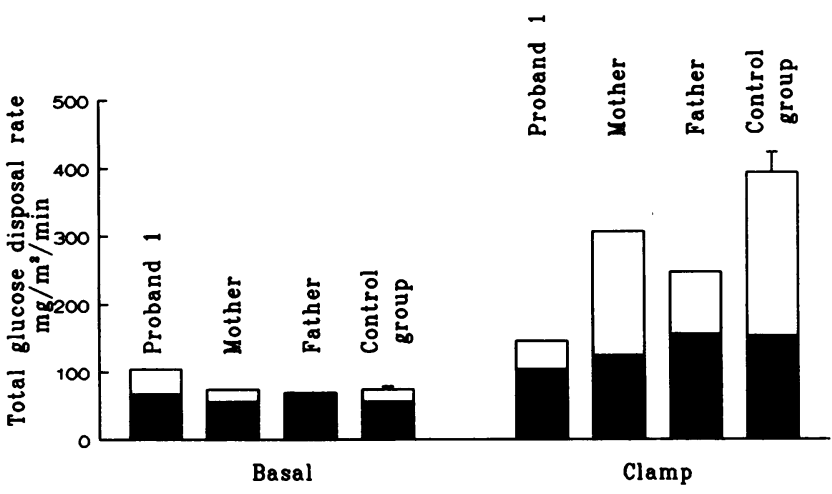

Figure 1. Total glucose disposal rate as well as oxidative (solid bars) and nonoxidative (open bars) glucose metabolism in proband 1 , his parents, and a control group (as characterized in Table I) during the basal period and after $4 \mathrm{~h}$ of hyperinsulinemia $\left(2 \mathrm{mU} \mathrm{kg}^{-1} \mathrm{~min}^{-1}\right)$. Basal oxidative and nonoxidative glucose metabolism was increased in the proband when compared with both his parents and the control group. During insulin infusion, however, total glucose disposal rate was severely decreased in the proband and to a lesser extent in his parents, when compared with the control group. This decrease was mainly due to a decrease in nonoxidative glucose metabolism.
During the hyperinsulinemic clamp, the steady-state serum insulin levels were $4,355,2,417,1,007$, and $1,002 \pm 163 \mathrm{pmol} /$ liter, and steady-state plasma glucose levels were 5.5, 5.1, 5.3, and $5.1 \pm 0.3 \mathrm{mmol} /$ liter in proband 1 , the father, the mother, and the control group, respectively.

Plasma levels of FFAs in the basal state were increased in proband $1(0.91 \mathrm{mmol} / \mathrm{liter})$, whereas in the parents (mother, $0.58 \mathrm{mmol} / \mathrm{liter}$; father, $0.40 \mathrm{mmol} / \mathrm{liter}$ ) and the control group $(0.48 \pm 0.13 \mathrm{mmol} /$ liter $)$ levels of plasma FFAs were comparable. During intravenous insulin infusions, plasma levels of FFAs were suppressed in the parents (mother, $0.03 \mathrm{mmol} / \mathrm{liter}$; father, $0.07 \mathrm{mmol} /$ liter $)$ and control subjects $(0.05 \pm 0.01 \mathrm{mmol} /$ liter $)$ whereas the serum level of FFAs was unchanged in proband 1 ( $1.02 \mathrm{mmol} / \mathrm{liter}$ ). No difference was found in lipid oxidation in the basal state among the participants (proband $1,35 \mathrm{mg} /$ $\mathrm{m}^{2} / \mathrm{min}$; mother, $32 \mathrm{mg} / \mathrm{m}^{2} / \mathrm{min}$; father, $34 \mathrm{mg} / \mathrm{m}^{2} / \mathrm{min}$; control group, $30 \pm 5 \mathrm{mg} / \mathrm{m}^{2} / \mathrm{min}$ ). During insulin infusion, lipid oxidation decreased in all participants. However, the suppression of lipid oxidation during insulin infusion was clearly impaired in proband $1\left(22 \mathrm{mg} / \mathrm{m}^{2} / \mathrm{min}\right)$ and to a lesser extent in the mother $\left(9 \mathrm{mg} / \mathrm{m}^{2} / \mathrm{min}\right)$ when compared with the father $\left(1 \mathrm{mg} / \mathrm{m}^{2} / \mathrm{min}\right)$ and the control group $\left(0.4 \pm 5 \mathrm{mg} / \mathrm{m}^{2} / \mathrm{min}\right)$.

Hepatic glucose output (HGO) was increased in the basal state in proband $1\left(104 \mathrm{mg} / \mathrm{m}^{2} / \mathrm{min}\right)$ when compared with both parents and the control group (mother, $71 \mathrm{mg} / \mathrm{m}^{2} / \mathrm{min}$; father, $75 \mathrm{mg} / \mathrm{m}^{2} / \mathrm{min}$; control group, $75 \pm 4 \mathrm{mg} / \mathrm{m}^{2} / \mathrm{min}$ ). During insulin infusion, HGO was fully suppressed in the parents and the control group (mother, $-22 \mathrm{mg} / \mathrm{m}^{2} / \mathrm{min}$; father, $-75 \mathrm{mg} / \mathrm{m}^{2} /$ $\mathrm{min}$; control group, $-87 \pm 12 \mathrm{mg} / \mathrm{m}^{2} / \mathrm{min}$ ). However, in proband 1, HGO remained increased, suggesting insulin resistance at the hepatic level $\left(70 \mathrm{mg} / \mathrm{m}^{2} / \mathrm{min}\right)$.

Insulin receptor binding and kinase activity. The effect of an increase in serum insulin concentration during the euglycemic hyperinsulinemic clamp on insulin receptor kinase (IRK) activity was measured in muscle biopsies from the parents and four of the control subjects (no analysis was done in the oldest boy with CFTDM because an inadequate amount of muscle tissue was available for analysis ) using a microtiter well assay system (Fig. 2). In the father the increase in IRK activity was only $\sim 50 \%$ of that in the control subjects despite a more than twofold higher level of serum insulin. Activation of IRK is almost linearly dependent of the insulin concentration in this concentration range (Klein, H. H., unpublished observation). Taking this into account, one can estimate that the insulin effect on IRK 


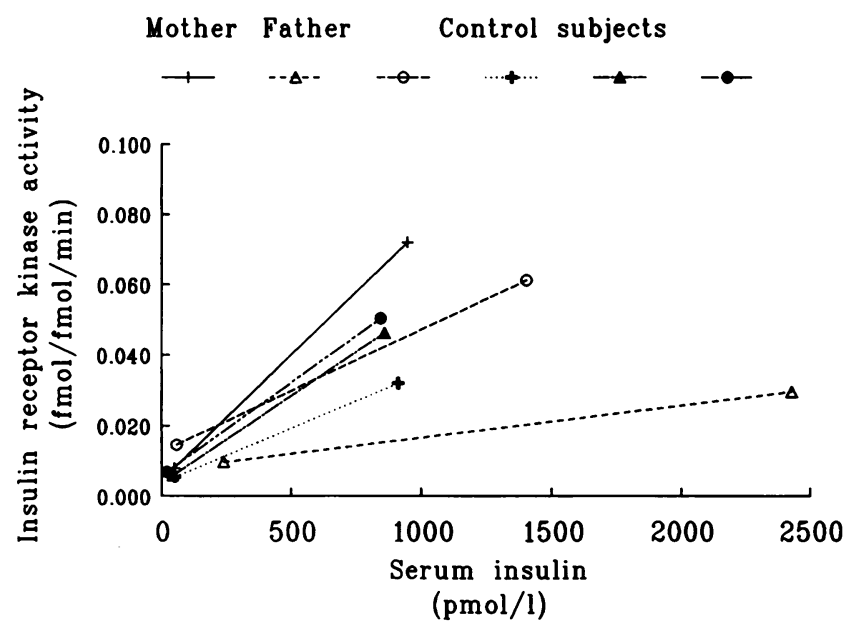

Figure 2. Muscle biopsies obtained at basal or clamp serum insulin levels were immediately frozen and then solubilized under conditions designed to preserve the activity state of the receptors as existed "in vivo"' ( see Methods). The solubilized proteins were then pipetted into microwells coated with anti-insulin receptor antibody. After insulin receptor immobilization, IRK activity and insulin binding activity in the wells were determined as described in Methods. IRK activity was expressed as fmoles of phosphate incorporated into substrate per fmoles of insulin binding activity per minute.

activity in the muscle of the father is decreased by $>70 \%$ compared with the controls.

Insulin binding activity was comparable in the parents and the control subjects in the basal state (mother, $1.23 \mathrm{fmol}$ of insulin binding activity per $\mathrm{mg}$ of muscle; father, $1.22 \mathrm{fmol}$ of insulin binding activity per mg of muscle; control, $1.43 \pm 0.16$ fmol of insulin binding activity per mg of muscle). However, during hyperinsulinemia, the binding activity was slightly lower in the mother and the father when compared with the control group (mother, $1.18 \mathrm{fmol}$ of insulin binding activity per $\mathrm{mg}$ of muscle; father, $1.10 \mathrm{fmol}$ of insulin binding activity per $\mathrm{mg}$ of muscle; control; $1.74 \pm 0.18 \mathrm{fmol}$ of insulin binding activity per mg of muscle).

GS mRNA. The abundance of the specific muscle-derived GS mRNA relative to rabbit $\beta$-globin mRNA (external control) was assessed using PCR technique. The relative amount of GS mRNA showed a two- to fourfold variation among the participants. However, the levels of GS-specific mRNA in proband 1 (basal biopsy only) and the parents (both basal and clamp biopsies) were comparable to the levels found in the control group, although a tendency to lower levels was seen in proband 1 and the father (Table III).

GS-immunoreactive protein level. The amount of GS immunoreactivity in homogenates from vastus lateralis muscle was quantitated by immunoblotting using anti-peptide antisera specific for GS. In all participants a dominant band of $84 \mathrm{kD}$ was identified for GS-immunoreactive protein (Fig. 3). Densitometric scanning of autoradiograms showed a decrease in the relative level of GS protein in the basal state in proband 1 (0.69 OD unit per $100 \mu \mathrm{g}$ of protein [percentage of internal standard]) and a tendency to a lower level in the mother ( 0.82 OD unit per $100 \mu \mathrm{g}$ of protein [percentage of internal standard]) when compared with both the father and the control group ( 0.99 and $0.96 \pm 0.06 \mathrm{OD}$ unit per $100 \mu \mathrm{g}$ of protein [percentage of internal standard], respectively) (Table III). $4 \mathrm{~h}$ of euglycemia and hyperinsulinemia did not give rise to any significant change in the immunoreactive protein level of GS in the control group $(0.99 \pm 0.05$ OD unit per $100 \mu \mathrm{g}$ of protein [percentage of internal standard], respectively) or in the GS level of the mother and the father $(0.83$ and 1.06 OD unit per $100 \mu \mathrm{g}$ of protein [percentage of internal standard], respectively) (Table III). No muscle biopsy was available during the clamp from proband 1 . Using the carboxy terminus anti-peptide antibody against GS, more minor bands with apparent molecular masses of 82-80 $\mathrm{kD}$ were dissociated from the dominant band with a molecular mass of $84 \mathrm{kD}$. The increased electrophoretic mobility of GS immunoreactivity may reflect the dephosphorylating effect of insulin on GS. In vivo insulin exposure had similar effects on GS immunoreactivity in muscle from control subjects and both parents (Fig. 3).

GS activity. Total GS activity of homogenates of vastus lateralis was similar in the father and the controls in the basal state as well as after insulin infusion (Table III). In the mother and proband 1 , however, total GS activity in the basal state was $\sim 40 \%$ lower when compared with levels in the control group. Fractional activity of GS in the basal state at the physiological concentration of G6P $(0.1 \mathrm{mmol} / \mathrm{liter})\left(\mathrm{FV}_{0.1}\right)$ was similar in the mother and the control group, whereas in the father and proband 1, the fractional activity of GS was $\sim 70$ and $47 \%$ lower, respectively, when compared with levels in the control group. Insulin infusion increased the fractional activity of GS equally in both the mother and the control group, but to a lesser extent in the father. The allosteric activation of GS by G6P was impaired in proband 1 and his father, as reflected by the fact that $\mathrm{A}_{0.5}$ was highly increased in proband 1 and less in the father when compared with the control group (Table III). $\mathrm{A}_{0.5}$ in the mother was comparable to that of the control group. During the hyperinsulinemic clamp, the decrement in $\mathrm{A}_{0.5}$ in the parents and the control group was comparable, i.e., the relative activation of GS by G6P was similar in these study participants.

\section{Discussion}

In this paper we characterize aspects of the insulin resistance in two brothers with CFTDM and their clinically healthy family. The CFTDM patients showed symptoms of marked insulin resistance, including severe fasting hyperinsulinemia and a diabetic glucose tolerance; the older boy was found to be severely insulin resistant, as evaluated by the euglycemic, hyperinsulinemic clamp method. To our knowledge this is the first finding of CFTDM in combination with severe insulin resistance and diabetes mellitus. Abnormalities of insulin action have generally been studied in insulin-resistant states, such as obesity and $\operatorname{NIDDM}(24,25)$, and to a lesser extent in other syndromes of extreme insulin resistance, i.e., acanthosis nigricans, type A insulin resistance, leprechaunism, and lipodystrophic syndromes (25). A series of different mutations in the insulin receptor gene are associated with some of the syndromes of severe insulin resistance, whereas postreceptor molecular defects are likely to be dominant in other cases of severe insulin resistance (25), as well as in obesity and insulin-resistant NIDDM $(24,25)$.

The patients previously described by Brooke as having CFTDM were diagnosed on the basis of a histochemical comparison of the diameters of both type 1 and type 2 muscle fibers, 
Table III. Effects of 4-h Euglycemic Hyperinsulinemia (2 mU/kg/min) on GS Enzyme Activity, Immunoreactive Protein, and mRNA

\begin{tabular}{|c|c|c|c|c|c|c|c|}
\hline & \multirow{2}{*}{$\frac{\text { Proband } 1}{\text { Basal }}$} & \multicolumn{2}{|c|}{ Mother } & \multicolumn{2}{|c|}{ Father } & \multicolumn{2}{|c|}{ Control group $(n=6)$} \\
\hline & & Basal & Clamp & Basal & Clamp & Basal & Clamp \\
\hline $\begin{array}{l}\text { Total GS activity (nmol of UDPG/mg } \\
\text { of protein } / \mathrm{min} \text { ) }\end{array}$ & 21.4 & 22.3 & 29.3 & 34.0 & 35.5 & $35.8 \pm 2.0$ & $41.8 \pm 2.9$ \\
\hline GS FV $\mathrm{FV}_{0.1}(\%)$ & 5.46 & 16.2 & 55.95 & 9.31 & 24.98 & $18.4 \pm 2.7$ & $48.9 \pm 2.3$ \\
\hline GS $A_{0.5}(n M)$ & 1.10 & 0.38 & 0.09 & 0.58 & 0.23 & $0.30 \pm 0.04$ & $0.09 \pm 0.01$ \\
\hline $\begin{array}{l}\text { GS protein (OD units } / 100 \mu \mathrm{g} \text { of } \\
\text { protein [\% of internal standard] })\end{array}$ & 0.69 & 0.82 & 0.83 & 0.99 & 1.06 & $0.96 \pm 0.06$ & $0.99 \pm 0.05$ \\
\hline GS mRNA (arb. units) & 2.08 & 3.46 & 3.29 & 2.20 & 2.24 & $2.91 \pm 0.32$ & $2.95 \pm 0.46^{*}$ \\
\hline
\end{tabular}

Values are mean $\pm \mathrm{SE}$ for control group. UDPG is UDP-Glucose. ${ }^{*} n=4$.

with type 1 fibers being increased in number and smaller than type 2 fibers by a margin of more than $12 \%$ (1). This contrasts with normal muscle morphology in children, in which type 1 and type 2 fibers are of approximately equal size (26). The clinical findings in the first described cases were very similar to those in other congenital nonprogressive myopathies, with a mild clinical course and some improvement with age (1). Recent studies have reported more severe clinical cases, with respiratory failure necessitating continuous assisted ventilation. These findings underline the clinical heterogeneity of CFTDM $(2,7)$. Therefore, despite fairly exact diagnostic criteria, CFTDM has remained a somewhat controversial entity. To define the clinical variation, an extensive analysis of 46 morphologically pure cases of CFTDM was recently undertaken (27). Based on these examinations, it was concluded that although the associated features and the clinical course appear to follow a uniform pattern in the majority of the cases, important exceptions exist, and CFTDM appears to remain a histological diagnosis with only some predictive clinical value (27).

Myotonic dystrophy (MD), the most common form of muscular dystrophy, is also characterized by hyperinsulinemia in response to an OGTT, and modest insulin resistance has been demonstrated using the euglycemic, hyperinsulinemic clamp technique (see reference 28 for review). MD is an autosomal dominant, multisystem disease carried on chromosome 19, with major symptoms arising from damage to skeletal muscle, cardiac, and smooth muscles and a wide spectrum of medical complications (28). Muscle biopsy often shows distinctive type 1 muscle fiber atrophy. In MD interest has focused on the relation-

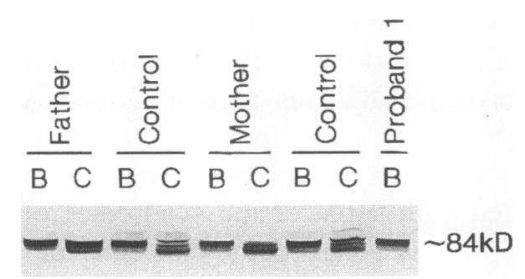

Figure 3. Autoradiograms of immunoblot analysis of GS protein levels in skeletal muscle (vastus lateralis) from proband 1, the father, the mother, and representative control subjects in

the basal state $(B)$ and after $4 \mathrm{~h}$ of euglycemia and hyperinsulinemia (C). No muscle biopsy was available during the clamp from proband 1. Using a carboxy terminus anti-peptide antibody against GS, a resolution of the dominant $84-\mathrm{kD}$ band into more minor bands of $82-80 \mathrm{kD}$ was recognized after $4 \mathrm{~h}$ of in vivo hyperinsulinemia. This finding may reflect the dephosphorylating effect of insulin. ship of insulin action and muscle anabolism, and it has been hypothesized that the degree of muscle wasting in MD is somehow related to the severity of insulin resistance (28).

In our study both glucose-tolerant parents to the CFTDM patients, in particular their father, showed insulin resistance during the clamp when compared with a control group, and interestingly, fasting hyperinsulinemia was also found in the father. The strikingly increased serum insulin levels in the CFTDM patients could not be explained by increased levels of proinsulin, since the two-site immunoassay used is highly specific and does not measure human proinsulin. This was further confirmed by measuring serum proinsulin levels during the OGTT: the levels of serum proinsulin were increased in the two boys when compared with both parents and their unaffected brother, probably reflecting a constant stress on pancreatic $\beta$ cell function. However, the two probands did not have an increased proportion of proinsulin to insulin compared with the unaffected brother, mother, and father.

We used the euglycemic hyperinsulinemic clamp technique in combination with indirect calorimetry and infusion of tritiated glucose to compare basal and insulin-stimulated glucose metabolism and lipid oxidation in the oldest boy affected with CFTDM, his parents, and a control group. A $62 \%$ decrease in insulin-stimulated total glucose disposal rate in the boy with CFTDM was demonstrated when compared with the control group, and this decrease was, under the chosen experimental conditions, accounted for predominantly by a severely decreased nonoxidative glucose metabolism and to a lesser degree by a decreased oxidative glucose metabolism.

None of the probands had acanthosis nigricans, a clinical feature frequently associated with congenital syndromes of severe insulin resistance (25). They both had growth retardation with severe muscle hypotrophy, a potential consequence of impaired insulin action on muscle cell differentiation and growth. The moderately insulin-resistant but glucose-tolerant father also had short stature.

CFTDM is a previously undescribed form of severe insulin resistance and diabetes that may be related to genetic defects at one or more steps in the cellular action of insulin. Insulin initiates its pleiotropic cellular effects by binding to the $\alpha$ subunit of its tetrameric plasma membrane receptor, which in turn results in a rapid autophosphorylation of specific tyrosine residues on the $\beta$ subunit (29). This activation further stimulates the tyrosine kinase activity of the receptor toward other protein 
substrates in the cascade of insulin action. Using a microtiter well assay system to measure in vivo insulin activation of the IRK, we found that the kinase activity was severely decreased in the father of the CFTDM patients when compared with both the mother and the control subjects. No analysis of IRK activity was done for any of the patients with CFTDM because of an inadequate amount of muscle tissue. However, the demonstration of a $>70 \%$ decrease in IRK activity in the father, who was characterized as having hyperinsulinemia in the fasting state and during the clamp, increased insulin response to an OGTT, and insulin resistance, made it likely that a defect or defects exist in insulin receptor function with or without mutations in the insulin receptor gene also in the patients with CFTDM. In fact, preliminary studies of the molecular genetics of this family have revealed that the affected brothers have inherited a mutation in the tyrosine kinase domain of the insulin receptor from their father and a deletion of exon 17 in part of their insulin receptor mRNA from their mother (30). Additionally, the two affected brothers have inherited a heterozygous missense mutation at codon 513 (alanine $\rightarrow$ proline) in insulin receptor substrate-1 from their father (30).

Under clamp conditions of euglycemia and hyperinsulinemia, insulin resistance is a prominent feature of many patients with NIDDM (31). Skeletal muscle has been shown to be the quantitatively dominant tissue of insulin resistance under these experimental conditions (24), and nonoxidative glucose metabolism, which reflects primarily muscle glycogen synthesis (32), represents the major intracellular pathway responsible for the insulin insensitivity $(31,33)$. Several abnormalities in the activation of muscle GS, which is a key enzyme in the glycogen synthesis pathway, have been reported in studies of patients with NIDDM. Insulin-stimulated glucose disposal rate was severely decreased in proband 1 and to a lesser degree in the parents when compared with the control group. The decrease was primarily due to a decrease in nonoxidative glucose metabolism, and in proband 1 it was paralleled by lower basal levels of muscle-specific GS mRNA, immunoreactive GS protein, GS activity, and impaired allosteric activation of GS by G6P when compared with the control group. Whether the impairment in expression of the GS gene is a primary phenomenon due to structural defects in GS itself or is secondary to the genetic abnormalities in the insulin receptor or insulin receptor substrate- 1 or in other key enzymes in the signaling pathway from the receptor to GS can at present only be speculated. Alternatively, the concomitant hormonal and metabolic disturbances might cause the alterations of GS expression. An abnormality anywhere in the complex pathway of GS activation could change the balance of GS from the active dephosphorylated form toward the less active phosphorylated form, thus contributing to insulin resistance $(34,35)$.

From studies of nondiabetic men, it has been suggested that myocyte size and myocyte fiber type may play important roles in the regulation of insulin sensitivity (36). A positive correlation was found between peripheral glucose uptake and the percentage of oxidative type 1 muscle fibers. Oxidative type 1 fibers are slow-twitch fibers known to be very sensitive to insulin, whereas type 2B slow-twitch fibers are less sensitive (36). Moreover, it has been demonstrated that insulin-stimulated glucose disposal rate is significantly increased in athletes compared with sedentary control subjects (37). The same athletes were characterized as having a $40 \%$ higher relative area of type 1 fibers in vastus lateralis muscle and a $75 \%$ lower area of type 2B fibers when compared with control subjects. Furthermore, a negative correlation between type $2 \mathrm{~B}$ muscle fibers and insulinstimulated glucose disposal rate was also demonstrated (37). CFTDM patients have an excess of small slow-twitch oxidative type 1 muscle fibers and normal or hypertrophied fast-twitch glycolytic type $2 \mathrm{~A}$ or $2 \mathrm{~B}$ fibers. Whether the distribution and type of muscle fibers in the CFTDM patients are primary or secondary to the insulin resistance as demonstrated in our patients is at present unknown.

\section{Acknowledgments}

The technical assistance of Lene Aabo, Annemette Forman, Bente Mottlau, and Helle Fjordvang is greatfully acknowledged.

This investigation was supported by grants from the Velux Foundation, Danish Diabetes Association, Danish Medical Research Council, Poul and Erna Sehested Hansens Foundation, Bernhard and Marie Kleins Foundation, Frimodt-Heineke Foundation, and Jacob Madsens and Olga Madsens Foundation.

\section{References}

1. Brooke, M. H. 1973. Congenital fiber type dysproportion. Clin. Studies Myol. Int. Congress Ser. 295:147-159.

2. Cavanagh, N. P. C., B. D. Lake, and P. Mcmeniman. 1979. Congenital fibre type disproportion myopathy. A histological diagnosis with an uncertain clinical outlook. Arch. Dis. Childh. 54:735-743.

3. Santoro, L., E. Del Giudice, D. Francica, A. Romano, G. Vita, and F. Barbieri. 1985. Congenital fiber type disproportion myopathy. Clin. Pediatr. 24:219-220.

4. Curless, R. G., and M. B. Nelson. 1977. Congenital fiber type disproportion in identical twins. Ann. Neurol. 3:455-459.

5. Kula, R. W., J. H. Sher, S. A. Shafiq, and J. Hardy-Stashin. 1980. Variability of clinical pathological manifestations in familial fiber type disproportion. Trans. Am. Neurol. Assoc. 105:416-419.

6. Sulaiman, A., H. M. Swick, and D. S. Kinder. 1983. Congenital fibre type disproportion with unusual clinico-pathologic manifestations. J. Neurol. Neurosurg. Psych. 46:175-182.

7. Lenard, H. G., and H. H. Goebel. 1975. Congenital fibre type disproportion. Neuropädiatrie. 6:220-231.

8. Laak, H. J., H. H. J. Jasper, F. J. M. Gabreëls, T. J. M. Breuer, R. C. A. Sengers, E. M. G. Joosten, A. M. Stadhouders, and A. A. W. M. Gabreëls-Festen. 1981. Congenital fibre type disproportion. Clin. Neurol. Neurosurg. 83:67-79.

9. Marolda, M. 1992. Congenital fiber type disproportion in two sisters. A clinical and histopathological study. Acta Neurol. Naples. 14:398-407.

10. Chang, J.-F., Y.-J. Jong, S.-C. Mak, and C.-H. Chiang. 1990. Congenital fiber type disproportion: report of one case. Acta Paediatr. Sin. 31:366-372.

11. DeFronzo, R. A., J. D. Tobin, and R. Andres. 1979. Glucose clamp technique: a method for quantifying insulin secretion and resistance. Am. J. Physiol. (Endocrinol. Metab.). 6:E214-E223.

12. Vestergaard, H., S. Lund, F. S. Larsen, O. J. Bjerrum, and O. Pedersen. 1993. Glycogen synthase and phosphofructokinase protein and mRNA levels in skeletal muscle from insulin resistant patients with non-insulin-dependent diabetes mellitus. J. Clin. Invest. 91:2342-2350.

13. Steele, R. 1959. Influence of glucose loading and of injected insulin on hepatic glucose output. Ann. NY Acad. Sci. 82:420-430.

14. Frayn, K. N. 1983. Calculation of substrate oxidation rates in vivo from gaseous exchange. J. Appl. Physiol. 55:628-634.

15. Klein, H. H., B. Kowalewski, M. Drenckhan, S. Neugebauer, S. Matthaei, and G. Kotzke. 1993. A microtiter well assay system to measure insulin activation of insulin receptor kinase in intact human mononuclear cells. Decreased insulin effect in cells from patients with NIDDM. Diabetes. 42:883-890.

16. Bak, J. F., and O. Pedersen. 1990. Exercise-enhanced activation of glycogen synthase in human skeletal muscle. Am. J. Physiol. (Endocrinol. Metab.). 258:E957-E963.

17. Andersen, I., and S. Hannibal. 1983. Analytical and economical optimization of a glucose method with immobilized enzymes. Journal of Automatic Chemistry. 5:188-192.

18. Andersen, L., B. Dinesen, P. N. Jørgensen, F. Poulsen, and M. E. Røder. 1993. Enzyme immunoassay for intact human insulin in serum or plasma. Clin. Chem. 39:578-582. 
19. Heding, L. G. 1975. Radioimmunological determination of human Cpeptide in serum. Diabetologia. 11:541-548.

20. Faber, O., C. Binder, J. Markussen, L. G. Heding, V. K. Naithani, H. Kuzuya, P. Blix, D. L. Horwitz, and A. H. Rubenstein. 1978. Characterization of seven C-peptide antisera. Diabetes. 27:170-177.

21. Hartling, S. G., B. Dinesen, A. Kappelgård, O. K. Faber, and C. Binder. 1986. ELISA for human proinsulin. Clin. Chim. Acta. 156:289-298.

22. Hother-Nielsen, O., O. Schmitz, J. F. Bak, and H. Beck-Nielsen. 1987. Enhanced hepatic insulin sensitivity, but peripheral insulin resistance in patients with type I (insulin-dependent) diabetes. Diabetologia. 30:834-840.

23. Itaya, K., and U. Michio. 1965. Colorimetric determination of free fatty acids in biological fluids. J. Lipid Res. 6:16-20.

24. DeFronzo, R. A., and E. Ferrannini. 1991. Insulin resistance. A multifaceted syndrome responsible for NIDDM, obesity, hypertension, dyslipidemia and atherosclerotic cardiovascular disease. Diabetes Care. 14:173-194.

25. Moller, D. E., editor. 1993. Insulin Resistance. John Wiley \& Sons Inc., New York. 425 pp.

26. Brooke, M. H., and W. K. Engel. 1969. The histographic analysis of human muscle biopsies with regard to fiber types. Neurology. 19:591-605.

27. Haltia, M., and S. Rehunen. 1988. Congenital fiber type disproportion in an adult: a morphometric and microchemical study. Acta Neurol. Scand. 78:6571.

28. Livingston, J. N., and R. T. Moxley. 1994. Myotonic dystrophy. Phenotype-genotype and insulin resistance. Diabetes Rev. 2:29-42.

29. Kahn, C. R., and M. F. White. 1988. The insulin receptor and the molecular mechanism of insulin action. J. Clin. Invest. 82:1151-1156.
30. Vestergaard, H., P. Vorwerk, C. Bjorbæk, P. De Meyts, and O. Pedersen. 1994. Congenital muscle fibre type disproportion myopathy characterized by insulin resistant diabetes and mutations in insulin receptor and insulin receptor substrate-1 genes. Diabetes. 43:145A, no. 453. (Abstr.)

31. DeFronzo, R. A., R. Bonadonna, and E. Ferrannini. 1992. Pathogenesis of NIDDM. A balanced overview. Diabetes Care. 15:318-368.

32. Shulman, G. I., D. L. Rothman, T. Jue, P. Stein, R. A. DeFronzo, and R. G. Shulman. 1990. Quantitation of muscle glycogen synthesis in normal subjects and subjects with non-insulin-dependent diabetes by ${ }^{13} \mathrm{C}$ nuclear magnetic resonance spectroscopy. N. Engl. J. Med. 322:223-228.

33. Bogardus, C., S. Lillioja, K. Stone, and D. M. Mott. 1984. Correlation between muscle glycogen synthase activity and in vivo insulin action in man. $J$. Clin. Invest. 73:1185-1190.

34. Stalmans, W., M. Bollen, and L. Mvumbi. 1987. Control of glycogen synthesis in health and disease. Diabetes/Metab. Rev. 3:127-161.

35. Cohen, P. 1986. Muscle glycogen synthase. In The Enzymes. P. D. Boyer and E. G. Krebs, editors. Harcourt Brace Jovanovich, Publishers, New York. 461 497.

36. Lillioja, S., A. A. Young, C. L. Culter, J. L. Ivy, W. G. H. Abbott, J. K. Zawadzki, H. Yki-Järvinen, L. Christin, T. W. Secomb, and C. Bogardus. 1987. Skeletal muscle capillary density and fiber type are possible determinations of in vivo insulin resistance in man. J. Clin. Invest. 80:415-424.

37. Andersen, P. H., S. Lund, O. Schmitz, S. Junker, B. B. Kahn, and O. Pedersen. 1993. Increased insulin-stimulated glucose uptake in athletes: the importance of GLUT4 mRNA, GLUT4 protein and fibre type composition of skeletal muscle. Acta Physiol. Scand. 149:393-404. 